University of Nebraska - Lincoln

DigitalCommons@University of Nebraska - Lincoln

USDA National Wildlife Research Center - Staff Publications
U.S. Department of Agriculture: Animal and Plant Health Inspection Service

3-1-2004

\title{
Food Habits of Lesser Scaup (Aythya affinis) Occupying Baitfish Aquaculture Facilities in Arkansas
}

\author{
David E. Wooten \\ United States Department of Agriculture, Agricultural Research Service
}

Scott J. Werner

USDA-APHIS-Wildlife Services, scott.j.werner@aphis.usda.gov

Follow this and additional works at: https://digitalcommons.unl.edu/icwdm_usdanwrc

Part of the Environmental Sciences Commons

Wooten, David E. and Werner, Scott J., "Food Habits of Lesser Scaup (Aythya affinis) Occupying Baitfish Aquaculture Facilities in Arkansas" (2004). USDA National Wildlife Research Center - Staff Publications. 402.

https://digitalcommons.unl.edu/icwdm_usdanwrc/402

This Article is brought to you for free and open access by the U.S. Department of Agriculture: Animal and Plant Health Inspection Service at DigitalCommons@University of Nebraska - Lincoln. It has been accepted for inclusion in USDA National Wildlife Research Center - Staff Publications by an authorized administrator of DigitalCommons@University of Nebraska - Lincoln. 


\title{
Food Habits of Lesser Scaup Aythya affinis Occupying Baitfish Aquaculture Facilities in Arkansas
}

\author{
DAvid E. WOOTEN ${ }^{1}$ And ScOtT J. Werner ${ }^{2}$ \\ United States Department of Agriculture, Agricultural Research Service, Harry K. Dupree \\ Stuttgart National Aquaculture Research Center, P.O. Box 860, 2955 Highway 130 East, \\ Stuttgart, Arkansas 72160 USA
}

\begin{abstract}
Lesser scaup Aythya affinis, mediumsized black and white diving ducks, were collected at Arkansas baitfish farms during November-December $1999(N=33)$, January-February $2000(N=39)$, and March-April $2000(N=22)$ to determine seasonal differences in their diet and their relative impact to baitfish production. The mass of gastrointestinal contents was used to determine the proportion of each diet item relative to all items recovered during stomach analyses. Chironomids were the primary food item recovered. Ten of $94(10.6 \%)$ scaup contained identifiable fish biomass. Fish bones and otoliths were found in an additional 14 scaup (14.9\%). All fish remains were identified (via otoliths) as those commonly produced at Arkansas baitfish farms (Cyprinidae). Other diet items (ranked by proportional mass) were vegetative seeds, snails, insects, crayfish, and other aquatic worms (class Oligochaeta). Scaup diets were similar among collection periods, between males and females, and between juvenile and mature ducks. We estimated the economic impact of lesser scaup to baitfish production based upon estimated duration of ducks at farms, the proportion of ducks containing fish, and scaup energetic requirements. Provided estimates of scaup abundance and the cost of bird harassment at a particular farm, economic thresholds (i.e., fish replacement cost as a function of scaup predation) will facilitate cost-effective decisions regarding bird damage management at Arkansas baitfish aquaculture facilities.
\end{abstract}

Arkansas has the largest baitfish aquaculture industry in the United States, encompassing 11,250 ha of production in 1998 (Collins and Stone 1999). Although baitfish aquaculture exists throughout Arkansas, the production of golden shiners

\footnotetext{
${ }^{1}$ Present address: United States Department of Interior, Bureau of Indian Affairs, Pacific Regional Office-Branch of Forestry, 2800 Cottage Way, Sacramento, California 95825 USA.

${ }^{2}$ Corresponding author's present address: United States Department of Agriculture, Animal and Plant Health Inspection Service, Wildlife Services, National Wildlife Research Center, 4101 LaPorte Avenue, Fort Collins, Colorado 80521 USA.
}

Notemigonus crysoleucas, goldfish Carassius auratus, and fathead minnows Pimephales promelas is located primarily in central Arkansas, east of Little Rock (Lonoke and Prairie counties). Most Arkansas baitfish acreage occurs along the Mississippi flyway where these facilities are occupied by many species of waterbirds.

Although much research has substantiated the existing or potential impacts to North American aquaculture from herons, egrets, pelicans, and cormorants (Stickley et al. 1992; Glahn and Brugger 1995; Stickley et al. 1995; Wywialowski 1999; King and Werner 2001; Werner et al. 2001; Glahn and Dorr 2002; Glahn et al. 2002), there is a paucity of information regarding the impacts of diving ducks (e.g., bluebill or lesser scaup Aythya affinis) on baitfish production. Philipp and Hoy (1997) reported that 45 of 223 scaup (20\%) collected at Arkansas baitfish facilities (in March 1995, and from December 1995 to March 1996) contained baitfish. These authors estimated that the replacement cost of golden shiners and goldfish consumed per scaup foraging bout was $\$ 0.04$ and $\$ 0.12$, respectively, based upon scaup abundance and consumption rate, and baitfish market values.

Afton et al. (1991) suggested that fish comprised $3.5 \%$ of lesser scaup diets. C. Custer (United States Geological Survey, personal communication) has also observed scaup feeding on fish in the tailwaters of hydroelectric dams when all other water was iced over. Most studies have not observed piscivory among lesser scaup (Cronan 1957; Harmon 1962; Rogers and Korschgen 1966; Bartonek and Hickey 1969; Dirschl 1969; Bartonek and Murdy 


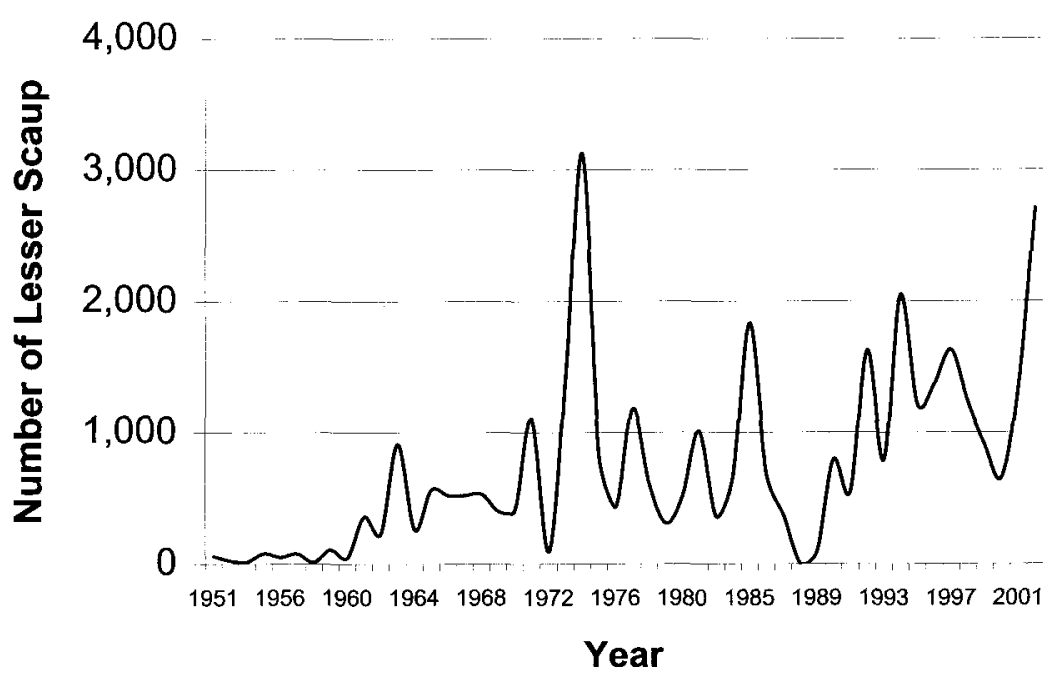

FigURE 1. Relative abundance (density within observation circles, 24-km diameter) of lesser scaup in Lonoke, Arkansas, from winter 1951-1952 through 2002-2003 based upon the Audubon Christmas Bird Count (National Audubon Society 2003).

1970; Kerwin and Webb 1971; Chabreck and Takagi 1985; Hoppe et al. 1986; Afton and Hier 1991; Mitchell and Carlson 1993; Moore et al. 1998; Lindeman and Clark 1999). Rather, amphipods, chironomids, leeches, aquatic plant seeds, and mollusks are the predominant food constituents of adult lesser scaup (Bartonek and Hickey 1969; Dirschl 1969; Bartonek and Murdy 1970; Afton and Hier 1991).

Baitfish aquaculture ponds are stocked at high densities and represent an abundant and easily accessible food source for piscivorous birds. Although many baitfish farmers believe that scaup consume baitfish at their farms, biological and economic information is needed to make reasonable decisions regarding bird damage management at these farms. This study was designed to provide such information by evaluating scaup diets at baitfish aquaculture facilities.

Although the North American breeding population of lesser scaup has declined over the last $20 \mathrm{yr}$ (Austin et al. 2000; Afton and Anderson 2001), local population increases have also been observed. For example, the abundance of lesser scaup wintering near the primary baitfish aquaculture area of Arkansas has generally increased in the last decade (National Audubon Society 2003; Fig. 1). In the absence of regular and systematic counts of lesser scaup occupying Arkansas baitfish farms, we present economic thresholds useful for evaluating the cost effectiveness of scaup damage management at a particular baitfish aquaculture facility.

\section{Materials and Methods}

Ninety-four lesser scaup were collected at ten baitfish farms in central and northeastern Arkansas from November 1999 though April 2000 (Lonoke, Prairie, and Greene counties). No effort was made to collect actively foraging ducks. Rather, the primary criterion for collecting a particular scaup was its presence on a baitfish pond. Scaup were collected (using shotguns and steel shot) during each of three collection periods: November-December $(N=33$ scaup among $11 \mathrm{~d}$ and five farms), January-February $(N=39$ among $13 \mathrm{~d}$ and seven farms), and March-April ( $N=22$ among $5 \mathrm{~d}$ and three farms). All specimens were collected after $0930 \mathrm{~h}$, since we observed heightened feeding activity by scaup from daylight through early afternoon.

We recorded the date, farm name and lo- 
cation, and county associated with scaup collections, and the body mass ( $\pm 0.1 \mathrm{~g}$ ), age class (juvenile, mature), and gender of collected birds. Wet mass ( $\pm 0.01 \mathrm{~g}$ ) of food items was used for analyses since the goal of this study was to determine impacts to baitfish production. Contents from the digestive tract above the gizzard were removed from each bird, weighed, and washed through U.S. standard sieves to concentrate contents. Gizzard contents were included in the sieved sample but were not weighed. Sieved contents were preserved in $70 \%$ ethanol for subsequent microscopy and taxonomic identification. Mass was used to determine the proportion of the diet that was attributable to each prey item. Scaup containing only bony fish parts were not used in proportioning the average mass of consumed baitfish per bird. Recovered fish otoliths were used to identify the species of fish consumed, but were not used to estimate prey biomass.

Previous investigators have hypothesized that the diets of lesser scaup differ between male and female ducks and among various reproductive stages during migration (Afton et al. 1991) and the breeding season (Afton and Hier 1991). Descriptive statistics (average \pm SEM) were used to summarize the average percentage of prey items recovered among collection periods, between male and female scaup, and between juvenile and mature birds collected during winter. Descriptive statistics were also used to characterize differences (i.e., males vs. females) in the mass of collected scaup and the mass of fish recovered during stomach analyses. The average mass of recovered fish was used to predict the economic impacts of lesser scaup foraging at Arkansas baitfish farms. The SEM of this parameter estimate (i.e., daily baitfish intake per scaup) was used to estimate baitfish replacement costs. Our economic predictions were further based upon the estimated duration of diving ducks at these farms and the current market value for cultured baitfish.

\section{Results}

\section{Diet Analysis}

The average body mass of male lesser scaup collected at baitfish farms $(N=63)$ was $765.4 \mathrm{~g}(\mathrm{SEM}=10.2$, range $=575.6-$ $909.3 \mathrm{~g})$. The average mass of female scaup $(N=31)$ was $708.5 \mathrm{~g}(\mathrm{SEM}=12.6$, range $=557.8-889.3 \mathrm{~g})$. Although scaup body mass varies seasonally, the average mass of these scaup were within ranges reported by Palmer (1976), Bellrose (1980), and Austin et al. (1998). The stomachs of eight scaup contained no discernable prey items. Most ducks contained one $(N=30)$ or two $(N=$ 29) prey items. Twenty-one stomachs contained three prey items, and six stomachs contained four items. Ten of 94 scaup ( $10.6 \%$ ) contained fish biomass (i.e., muscle, skin). Twenty-six percent of scaup showed evidence of fish consumption, though over half of these birds (15\%) contained only remains such as bones and/or otoliths that were not related to biomass. All fish remains were identified as fishes commonly produced at baitfish aquaculture facilities (i.e., Cyprinidae).

Among samples that contained a particular prey item, we recovered an average of $2.27 \mathrm{~g}$ of fish $(N=10), 2.10 \mathrm{~g}$ of chironomids $(N=39)$, and $1.57 \mathrm{~g}$ of crayfish $(N$ $=6)$. The mass of other prey items averaged less than $1.00 \mathrm{~g}$ among collected ducks. The average mass of prey items among scaup that contained at least one item $(N=86)$ was $2.13 \mathrm{~g} /$ duck (SEM $=$ 0.23 , range $=0.10-9.65 \mathrm{~g}$ ). Chironomids were the primary food item recovered during food habits analyses (by average diet proportion; Fig. 2). Other diet items (ranked by proportional mass) were vegetative seeds, snails, insects, fish, crayfish, and aquatic worms (class Oligochaeta).

Scaup diets were similar among collection periods (Table 1). We observed more chironomids among scaup collected in January-February than those collected in March-April. We recovered more cyprinid fish from birds collected in November-De- 


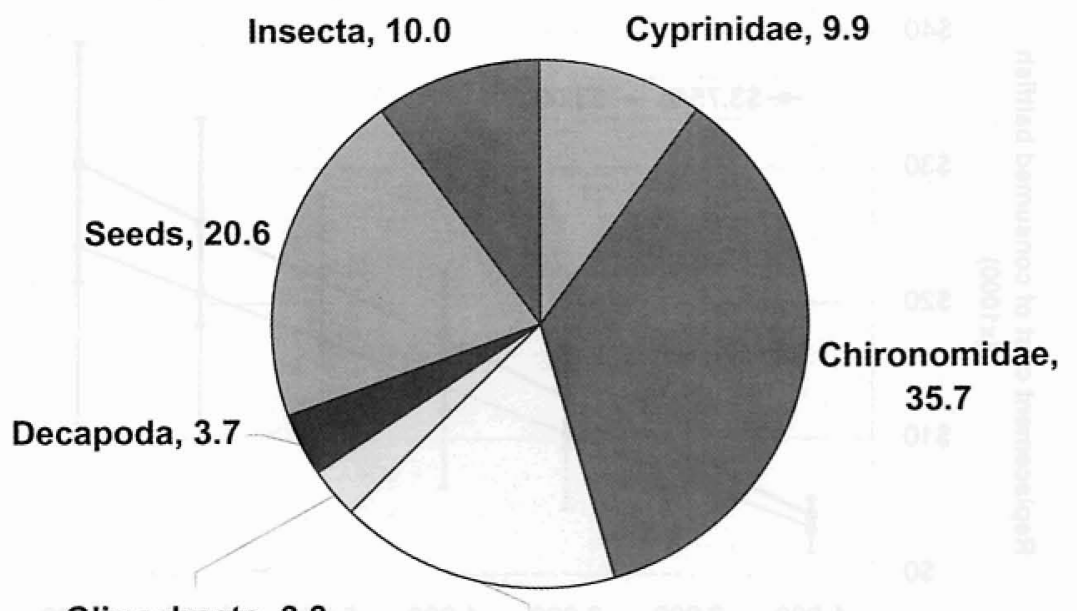

Oligochaeta, 3.3

\section{Gastropoda,}

16.7

FIGURE 2. Average percentage (by mass) of prey items recovered from stomachs of lesser scaup $(\mathrm{N}=86$ ) collected at Arkansas baitfish farms from November 1999 through April 2000.

cember than those collected in JanuaryFebruary. We recovered no crayfish (decapods) from birds collected in March-April. Relative to other collection periods, scaup collected in March-April contained most insects. Similarly, birds collected in January-February and November-December contained most oligochaets and seeds, respectively (Table 1).

The average mass of fish in the stomachs of male $(N=6)$ and female $(N=4)$ scaup that contained fish biomass was $1.89 \mathrm{~g}$ $(\mathrm{SEM}=0.89)$ and $2.84 \mathrm{~g}(\mathrm{SEM}=1.05)$, respectively. Although the diets of male and female scaup were similar, more insects and oligochaets were found in the stomachs of males vs. females (Table 1). We also observed few differences in the diets of juvenile vs. mature scaup (Table 1).

\section{Economic Impacts}

We estimated the economic impact of lesser scaup depredation at Arkansas baitfish farms based upon: 1) the number of days that diving ducks are present at these farms; 2) the proportion of scaup that con-

TABLE 1. Comparisons among average ( \pm SEM) percentages of prey items (by mass) recovered from lesser scaup collected from November 1999 through April 2000 at Arkansas baitfish farms.

\begin{tabular}{|c|c|c|c|c|c|c|c|c|}
\hline Comparison & Chironomida & Cyprinidae & Decapoda & Gastropoda & Insecta & $\begin{array}{l}\text { Oligo- } \\
\text { chaeta }\end{array}$ & Seeds & $N$ \\
\hline \multicolumn{9}{|l|}{ Collection period } \\
\hline Nov-Dec & $18.2 \pm 5.4$ & $11.7 \pm 4.7$ & $2.2 \pm 1.4$ & $8.8 \pm 2.9$ & $1.8 \pm 0.9$ & $0.7 \pm 0.5$ & $20.2 \pm 3.9$ & 33 \\
\hline Jan-Feb & $27.0 \pm 4.4$ & $1.3 \pm 1.3$ & $3.4 \pm 1.9$ & $10.5 \pm 2.9$ & $4.0 \pm 1.5$ & $3.6 \pm 1.5$ & $9.6 \pm 3.0$ & 39 \\
\hline Mar-Apr & $14.5 \pm 5.2$ & $5.2 \pm 4.3$ & $0.0 \pm 0.0$ & $10.0 \pm 3.6$ & $15.3 \pm 5.6$ & $0.9 \pm 0.4$ & $4.3 \pm 2.0$ & 22 \\
\hline \multicolumn{9}{|l|}{ Gender } \\
\hline Male & $19.1 \pm 3.5$ & $5.1 \pm 2.3$ & $1.9 \pm 1.2$ & $9.4 \pm 2.1$ & $7.7 \pm 2.2$ & $2.6 \pm 1.0$ & $12.6 \pm 2.6$ & 63 \\
\hline Female & $24.8 \pm 5.2$ & $7.4 \pm 4.1$ & $2.7 \pm 1.7$ & $10.6 \pm 3.2$ & $2.1 \pm 1.0$ & $0.6 \pm 0.4$ & $11.1 \pm 3.0$ & 31 \\
\hline \multicolumn{9}{|l|}{ Age } \\
\hline Juvenile & $19.5 \pm 7.3$ & $13.1 \pm 6.0$ & $2.2 \pm 2.2$ & $12.1 \pm 4.9$ & $2.7 \pm 1.5$ & $1.1 \pm 0.8$ & $15.6 \pm 5.2$ & 20 \\
\hline Mature & $17.7 \pm 1.0$ & $6.6 \pm 0.9$ & $1.1 \pm 0.2$ & $7.2 \pm 0.6$ & $2.2 \pm 0.3$ & $0.6 \pm 0.1$ & $21.8 \pm 0.9$ & 26 \\
\hline
\end{tabular}




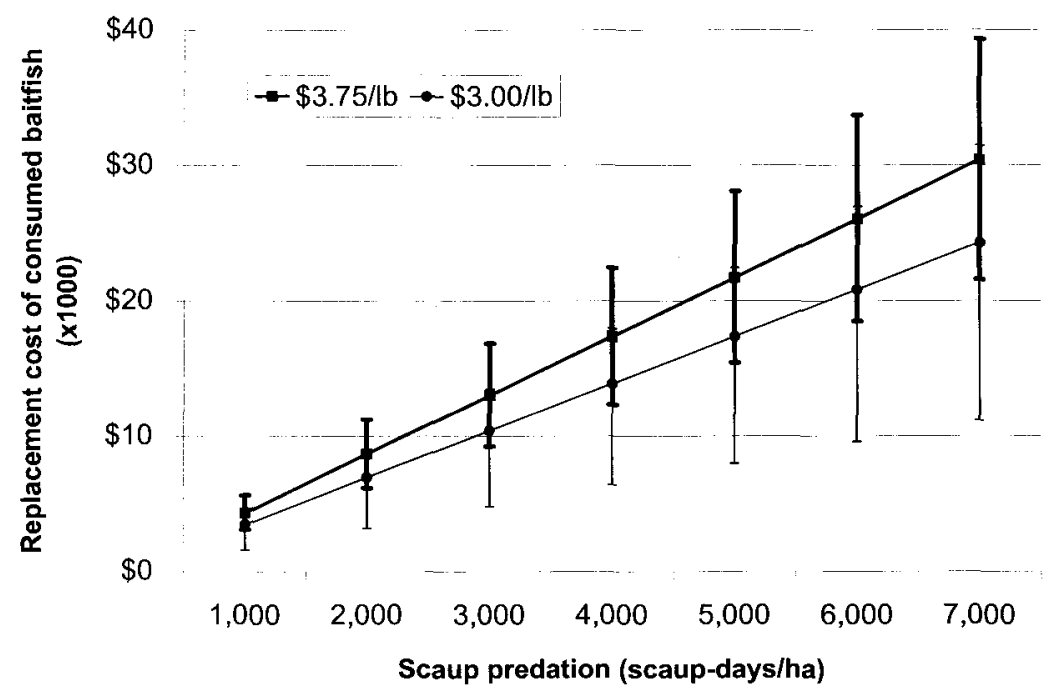

FIGURE 3. Estimated replacement cost ( \pm SEM) of baitfish consumed by lesser scaup at Arkansas baitfish aquaculture facilities at relatively high and low baitfish market values.

tained fish biomass; and 3) the relative contribution of cyprinid fishes, invertebrates, and plant material to the net energy needed to maintain adult scaup. Baitfish farmers in central Arkansas experience diving ducks at their farms from November though March each year (Werner and Wooten 1999). Most (>75\%) diving ducks observed at baitfish farms (average size $=202$ ha) during the present study were lesser scaup.

Among samples that contained a particular prey item, the average mass of fish, invertebrates, and plant material was $2.27 \mathrm{~g}$, $5.54 \mathrm{~g}$, and $0.46 \mathrm{~g}$, respectively. We estimated the energy density of cyprinid fishes as $1.33 \mathrm{kcal} / \mathrm{g}$ (wet mass; Hartman and Brandt 1995) based on the dry matter content of minnows (26\%; Cui and Wootton 1988). The fresh-mass energy density of invertebrates and plant material was estimated as $0.91 \mathrm{kcal} / \mathrm{g}$ and $0.57 \mathrm{kcal} / \mathrm{g}$, respectively (Stiven 1961). We estimated the average energy content of recovered prey items as the product of average mass and energy density of these items ( $\Sigma=8.32 \mathrm{kcal})$.

Based on the mass of birds in our study and their observed diet, lesser scaup should replenish observed gut contents an average of 10.8 times per day to procure the net energy needed for their maintenance $\left(\mathrm{NE}_{\mathrm{m}}\right.$ $\sim 90 \mathrm{kcal}=111.5 * \mathrm{~kg}$ body weight $^{0.75}$; Sugden and Harris 1972). Thus, lesser scaup may consume approximately $32.61 \mathrm{kcal}$ $(24.5 \pm 7.2 \mathrm{~g})$ of minnows/duck per d (i.e., the product of average fish mass in samples, energy density of cyprinids, and frequency of gut replenishment). Assuming: 1) that ducks occupy a particular farm each day from November through March (150 d), and 2) that $10.6 \%$ of these ducks consume baitfish, the replacement cost (Fig. 3) of consumed baitfish at 1,050 scaup-days/ha on a 200-ha farm $(1,400$ scaup present, or 150 scaup consuming baitfish) would be $\$ 3,610$ and $\$ 4,515$ at relatively low $(\$ 3 / \mathrm{lb})$ and high $(\$ 3.75 / \mathrm{lb} ; \mathrm{H}$. Thomforde, University of Arkansas-Pine Bluff, personal communication) baitfish market values, respectively. These costs would be $\$ 23,990$ and $\$ 29,990$, respectively, at 6,975 scaup-days/ ha on a 200 -ha farm $(9,300$ scaup present, or 985 scaup consuming baitfish; Fig. 3).

\section{Discussion}

We did not observe a predominance of baitfish in stomachs of lesser scaup collected at Arkansas baitfish farms. In contrast to previous observations regarding the bio- 
mass of golden shiners (approximately $7 \mathrm{~g}$, $N=20$ ) and goldfish (approximately $15 \mathrm{~g}$, $N=20$ ) within the esophagus and gizzard of lesser scaup collected at Arkansas baitfish facilities (Philipp and Hoy 1997), we recovered an average of $2.3 \mathrm{~g}$ of fish from ten scaup that contained fish biomass. In contrast to most studies that have not observed piscivory among scaup, however, our observations of lesser scaup diet composition were similar to those reported by Philipp and Hoy (1997; crustaceans, minnows, gastropods, insects, vegetation). Among ducks in the present study that contained at least one prey item, approximately $28 \%$ ( 24 of 86 scaup) contained fish remains. This observation is comparable to that of Philipp and Hoy (1997; 45 of 161 scaup, or $28 \%$ ).

Our estimates of economic impacts were conservatively derived (i.e., assuming $10.6 \%$ of scaup at baitfish farms consume baitfish). Subsequent studies regarding the rate of fish biomass digestion and otolith erosion in fish-eating birds will enhance the reliability of these economic predictions. Whereas the activity and availability of aquatic invertebrates influence the foraging behavior of dabbling and diving ducks (Swanson 1977; Sjoberg and Danell 1982), additional research is needed to evaluate the availability and selection of non-fish prey items in relation to baitfish consumption by diving ducks at aquaculture facilities.

Given the relative stability (e.g., baitfish density through time, chironomid presence throughout study area) in the availability of prey items recorded in this study, observed differences in diet composition among collection periods may be attributable to dynamic nutrient requirements of wintering scaup subsequent and prior to their autumn and spring migrations, respectively. Few differences, however, existed between the diets of male and female, and juvenile and mature lesser scaup during the breeding season (Afton and Hier 1991), summer (Bartonek and Murdy 1970), migration (Af- ton et al. 1991), and winter (this study, Afton et al. 1991).

The cost of efficient damage management strategies should not exceed the replacement cost of marketable baitfish lost to predation. Thus, estimates of baitfish mortality (i.e., unmarketable fish in the absence of predation) will enable aquaculture producers to reliably apply thresholds of avian depredation when making management decisions. Moreover, effective predictions regarding wildlife impacts are dependent upon the reliability of abundance estimates throughout the period of depredation. Philipp and Hoy (1997) suggested that unusually large numbers of diving ducks were observed at Arkansas baitfish farms during the winters of 1994-1995 and 19951996. These authors also suggested that flocks of 200-1,000 diving ducks are commonly found around baitfish facilities, and as many as 2,000 diving ducks may inhabit a baitfish facility during the spring and fall migration (Philipp and Hoy 1997). Current depredation thresholds and seasonal estimates of fish-eating bird abundance will enable aquaculture producers to determine the cost-effectiveness of their damage management practices.

\section{Acknowledgments}

We wish to thank T. Booth (Arkansas State Director, United States Department of Agriculture/Animal and Plant Health Inspection Service/Wildlife Services), M. Hoy (District Supervisor, USDA/APHIS/ Wildlife Services-AR), and M. Kearby (Wildlife Biologist, USDA/APHIS/Wildlife Services-AR) for their efforts in obtaining specimens for this study. Drs. S. C. Barras, A. Radomski, and M. E. Tobin provided useful feedback on a previous draft of this manuscript. We are also grateful to Dr. L. Rudstam (Senior Research Associate, Cornell Biological Field Station) for providing fish bioenergetics information, and Dr. $\mathrm{H}$. Thomforde (Extension Fisheries Specialist, University of Arkansas-Pine Bluff) for 
summarizing current trends in cultured baitfish market values.

\section{Literature Cited}

Afton, A. D. and M. G. Anderson. 2001. Declining scaup populations: a retrospective analysis of long-term population and harvest survey data. Journal of Wildlife Management 65:781-796.

Afton, A. D. and R. H. Hier. 1991. Diets of lesser scaup breeding in Manitoba. Journal of Field Ornithology 62:325-334.

Afton, A. D., R. H. Hier, and S. L. Paulus. 1991. Lesser scaup diets during migration and winter in the Mississippi flyway. Canadian Journal of Zoology 69:328-333.

Austin, J. E., A. D. Afton, M. G. Anderson, R. G. Clark, C. M. Custer, J. S. Lawrence, J. B. Pollard, and J. K. Ringelman. 2000. Declining scaup populations: issues, hypotheses, and research needs. Wildlife Society Bulletin 28:254263.

Austin, J. E., C. M. Custer, and A. D. Afton. 1998. Lesser scaup (Aythya affinis). In A. Poole and F. Gill, editors. The Birds of North America, no. 338. The Birds of North America, Inc., Philadelphia, Pennsylvania, USA.

Bartonek, J. C. and J. J. Hickey. 1969. Food habits of canvasbacks, redheads, and lesser scaup in Manitoba. Condor 71:280-290.

Bartonek, J. C. and H. W. Murdy. 1970. Summer foods of lesser scaup in subarctic taiga. Arctic 23: $35-44$.

Bellrose, F. C. 1980. Ducks, geese, and swans of North America, third edition. Stackpole Books, Harrisburg, Pennsylvania, USA.

Chabreck, R. H. and T. Takagi. 1985 . Foods of lesser scaup in crayfish impoundments in Louisiana. Proceedings of the Annual Conference of the Southeastern Association of Fish and Wildlife Agencies 39:465-470.

Collins, C. and N. M. Stone. 1999. Arkansas aquaculture valued at $\$ 162.8$ million in 1998 . Aquaculture Magazine 25(4):64-66.

Cronan, J. M. 1957. Food and feeding habits of the scaups of Connecticut waters. Auk 74:459-468.

Cui, Y. and R. J. Wootton. 1988. Effects of ration, temperature and body size on the body composition, energy content and condition of the minnow, Phoxinus phoxinus (L.). Journal of Fish Biology 32:749-764.

Dirschl, H. J. 1969. Foods of lesser scaup and bluewinged teal in the Saskatchewan River delta. Journal of Wildlife Management 33:77-87.

Glahn, J. F. and K. E. Brugger. 1995. The impact of double-crested cormorants on the Mississippi delta catfish industry: a bioenergetics model. Colonial Waterbirds 18 (Special Publication 1): 168175.
Glahn, J. F. and B. S. Dorr. 2002. Captive doublecrested cormorant Phalacrocorax auritus predation on channel catfish Ictalurus punctatus fingerlings and its influence on single-batch cropping production. Journal of the World Aquaculture Society 33:85-93.

Glahn, J. F., B. Dorr, J. B. Harrel, and L. Khoo. 2002. Foraging ecology and depredation management of great blue herons at Mississippi catfish farms. Journal of Wildlife Management 66:194201.

Harmon, B. G. 1962. Mollusks as food of lesser scaup along the Louisiana coast. Transactions of the North American Wildlife and Natural Resources Conference 27:132-138.

Hartman, K. J. and S. B. Brandt. 1995. Estimating energy density in fish. Transactions of the American Fisheries Society 124:347-355.

Hoppe, R. T., L. M. Smith, and D. B. Wester. 1986. Foods of wintering diving ducks in South Carolina. Journal of Field Ornithology 57:126-134.

Kerwin, J. A. and L. G. Webb. 1971. Foods of ducks wintering in coastal South Carolina, 1965-1967. Proceedings of the Annual Conference of the Southeastern Association of Fish and Wildlife Agencies 25:223-245.

King, D. T. and S. J. Werner. 2001. Daily activity budgets and population size of American white pelicans wintering in south Louisiana and the delta region of Mississippi. Waterbirds 24:250-254.

Lindeman, D. H. and R. G. Clark. 1999. Amphipods, land-use impacts, and lesser scaup (Aythya affinis) distribution in Saskatchewan wetlands. Wetlands 19:627-638.

Mitchell, C. A. and J. Carlson. 1993. Lesser scaup forage on zebra mussels at Cook Nuclear Plant, Michigan. Journal of Field Ornithology 64:219_ 222.

Moore, J. L., W. L. Hohman, T. M. Stark, and G. A. Weisbrich. 1998. Shot prevalences and diets of diving ducks five years after ban on use of lead shotshells at Catahoula Lake, Louisiana. Journal of Wildlife Management 62:564-569.

National Audubon Society. 2003. The Christmas bird count historical results [Online]. At http:// www.audubon.org/bird/cbe (2003).

Palmer, R. S. 1976. Handbook of North American birds, volume 1. Yale University, New Haven, Connecticut, USA.

Philipp, M. C. and M. D. Hoy. 1997, Lesser scaup depredation and economic impact at baitfish facilities in Arkansas. Pages 156-161 in C. D. Lee and S. E. Hygnstrom, editors. Thirteenth Great Plains Wildlife Damage Control Workshop Proceedings. Kansas State University Press, Manhattan, Kansas, USA.

Rogers, J. P. and L. J. Korschgen. 1966. Foods of lesser scaups on breeding, migration, and winter- 
ing areas. Journal of Wildlife Management 30 : $258-264$.

Sjoberg, K. and K. Danell. 1982. Feeding activity of ducks in relation to diel emergence of chironomids. Canadian Journal of Zoology 60:13831387.

Stickley, A. R., Jr., J. F. Glahn, J. O. King, and D. T. King. 1995. Impact of great blue heron depredations on channel catfish farms. Journal of the World Aquaculture Society 26:194-199.

Stickley, A. R., G. L. Warrick, and J. F. Glahn. 1992. Impact of double-crested cormorant depredations on channel catfish farms. Journal of the World Aquaculture Society 23:192-198.

Stiven, A. E. 1961 . Food energy available for and required by the blue grouse chick. Ecology 42:547553.
Sugden, G. L. and L. E. Harris. 1972. Energy requirements and growth of captive lesser scaup. Poultry Science 51:625-633.

Swanson, G. A. 1977. Diel food selection by Anatinae on a waste-stabilization system. Journal of Wildlife Management 41:226-231.

Werner, S. J. and D. E. Wooten. 1999. Fish-eating bird impacts in Arkansas: where and when? Aquaculture Magazine 25(6):70-73.

Werner, S. J., M. E. Tobin, and P. B. Fioranelli. 2001. Great egret preference for catfish size classes. Waterbirds 24:381-385.

Wywialowski, A. P. 1999. Wildlife-caused losses for producers of channel catfish Ictalurus punctatus in 1996. Journal of the World Aquaculture Society 30:461-472. 